THICKNESS OF THE PALEOZOIC STRATA

\title{
OF NORTHEASTERN IOWA.
}

ธิ

WILLIAM HARMON NORTON. 
4 


\section{THICKNESS OF THE PALEOZOIC STRATA OF}

NORTHEASTERN IOWA.

BY WILLIAM IIARMON NORTON.

The data upon which the following report is based are driller's records of deep borings in northeastern Iowa and examinations of sample-drillings of the different strata penetrated.

It is well to mention here the presence of certain difficulties which have attended the investigation. These were chiefly in the character and extent of the data at hand. Some of these difficulties have been readily met. No observer, however inexperienced, could assign the cinders, slack and coal sometimes found in samples in considerable quantity to any other horizon than the ash heap of the engine house, nor the iron filaments which surround the magnet when plunged in the drillings and the rusty particles which often cemented a few grains together, to any. other cause than the abrasion of drill and rods.

In the inspection of these drillings it must always be kept in mind that the vibration of ropes and rods and the lifting and lowering of the drill detach fragments of the rocks from far above the bottom of the boring. From shales and incoherent sandstones a large admixture of shale and sand is expected with the drillings of the rocks subjacent. When strata of sandstone or shale alternate 
rapidly with other rocks, the discrimination is one of peculiar difficulty and it is probable that the thickness of sandstone and shales has frequently been overestimated for this reason; drillings of the underlying rocks being masked in the samples by the material fallen from above. Drillings for example below the Saint Peter and from various horizons in the Cambrian often consist of finely comminuted arenaceous and dolomitic material intermixed. It then becomes a delicate question to decide whether the sand is entirely foreign, fallen from water-washed and incoherent sandstones above, and the drillings represent a pure dolomite, or whether the sand is partially extraneous and partly native, and the sample represents according to the proportion of silica, arenaceons dolonite or calciferous sandstone. The same doubt must frequently arise as to whether the silica in such drillings when native is disseminated or exists in thin layers of interbedded sandstones. The problem is made more intricate by the fact that, in artesian wells, drillings below the Saint Peter are often more or less sorted by the action of the water, being brought to the surface by the outflow of water, instead of by the sand-pump. When samples of each stratum are furnished, the errors resulting from these causes can be largely eliminated, but when only one sample is provided for scores or a hundred feet and the location of that sample within these limits is unknown, complete correction is impossible. The record of drillers, who in the "chuck" of the drill, the wear upon it and the length of the "runs" have other means of information, is often of assistance in interpreting the drillings. But experience very seriously invalidates determinations based upon records alone. Serious discrepancies exist between records of different wells in the same town, between the records of the boring 
and the reaming of the same well, and between the record and the series of sample drillings. Granular and arenaceous limestones are sometimes set down as sandstones and quartzites or dolomites as granites. Shales are made excessively thick, and scores or hundreds of feet of alternating heterogeneous strata are included under one designation. Drillings usually correct these errors; but when incomplete they may strengthen them. Thus, drillers' records failing to distinguish between limestone of different beds, as the Galena and Trenton, may include both under one head, "limestone so many feet thick," and leave the first sample drilling taken-or the last- to represent the entire group. It is believed that this will readily account for several cases in which formations appear to be wanting locally.

In the discrimination of the drillings which of ten came in the unpromising form of paste or powder, the rocks being completely pulverized by the drill, ordinary optical tests were supplemented by examinations with a petrographical microscope and by various chemical and mineralogical tests. Polarized light was used in discriminating for examplc between crystalline silica and non-crystalline and other minerals; while the relative proportion of different minerals in the drillings could of ten be decided by their relative proportions in the microscopic field. Limestones, dolomites and magnesian limestones were often treated with cold dilute hydrochloric acid, the residue observed, the solutions neutralized with ammonium carbonate and treated successively with ammonium oxalate and hydric disodic phosphate. The relative amounts of magnesia present. in different limestones could thus be roughly estimated. Time permitted no exact quantitative tests. 
In co-ordinating the strata of the well sections with the different geological formations, in rare instances a definite horizon may be recognized by the fortunate presence of some fossil fragment in the drillings. The means chiefly used, however, must be lithological similarity and order of superposition. So uniform, so well marked, and so widely diverse are the lithological characteristics of the rocks of the terranes outcropping in northeastern Iowa, and so constant also the order of their superposition, that when the drillings show unmistakably the mineralogical nature of any rock at any depth, little hesitancy need be felt in referring it to its appropriate place in the geological column. At the same time, due account must be taken of the true possible thinning out of any formation in passing westward and sonthward from its outcrop; of changes in its physical features, and of the intercalation of other terranes without superficial exposure within the limits of the state. In some instances also the structure of the rock, as for instance its porosity or incoherence making it a water-way, and the known thickness of a rock at its outcrop and its dip becomes facts of assistance in its correlation.

The frankest statement of the difficulties encountered in these investigations cannot, after all, destroy the substantial value of their results. Upon the results of such investigations only we can rely for all our knowledge of the vast underground extension of each geological formation ; compared with which the area of its outcrop is insignificant. This knowledge is not only of high scientific interest and value but it is also of great practical worth. It bear's directly upon the subject of artesian waters, the necessary conditions of the existence in Iowa of natural oil and gas in commercial quantities are matters of the 
altitude, and minerological and physical conditions of certain Paleozoic formations,- facts that can be determined only by exploitation of the drill.

It is a pleasure to acknowledge here the hearty co-operation of the many who have aided in collecting and preserving the data upon which this work is based. While the number of persons thus contributing to the work is large, grateful acknowledgement is due and is hereby rendered to all. So hearty indeed has been the co-operation of these persons that in no case has there been a failure to obtain drillings where they have been preserved. It is only to be regretted that in many cases deep wells have been bored at a considerable expense and yet no record of the strata is now extant.

It is to be hoped that in the future no deep borings will be made in the state withont some trustworthy person obtaining a complete and accurate record and series of sample drillings. Such a record should contain all matters of observation and judgment of the drillers, and samples of the drillings should be taken whenever change in the rock occurs, and in any case, every ten or twenty feet. The drillings should be emptied directly into a box from the last of the sand pumpings of each "clearing out" and immediately labeled with depth from which they were obtained.

Certainly self interest should prompt employers to secure and preserve such data respecting their own property, and yet a considerable number of water works in the state depending upon artesian waters are without these facts so important in case of many possible contingencies to their wells and in case that additional wells are desired. In some instances even the depth of the water horizons are unknown, and yet many thousands of dollars have been 
fruitlessly spent in Iowa in deep borings below water horizons which the knowledge of such facts might have saved.

In the course of the investigation some twenty different well sections were examined, sixteen of which have been correlated. These allow themselves to be arranged in two lines, one ruming from Emmetsburg to Davenport and the other from McGregor to Centerville. Thus two sections of the underlying strata have been made. The first reaches from Davenport northwest and is based upon records of wells drilled at Davenport, Tipton, Cedar Rapids, Vinton, Ackley, Mason City and Emmetsburg. The second starting from above Dubuque includes the section on the Mississippi and the wells of Monticello, Cedar Rapids, Sigourney, Ottumwa and Centerville.

The correlation of the strata encountered in these wells is shown on the accompanying charts (plates xvii and xviii).

The Cretaceous and Upper Carboniferous appear so seldom in the well sections that they need not be here considered. Beginning, however, with the Lower Carboniferous the different formations down to Algonkian are widely recognized, frequently with considerable detail.

\section{LOWER CARBONIFEROUS.}

While a lack of certitude exists as to the precise limits of the series in several well sections, one impressive fact is clearly shown; that of the relative decrease of the limestone compared with its shales and their almost complete disappearance in its southwestern extension. At Centerville for example, from 500 to 1,240 feet-and surely within these wide limits the Lower Carboniferous must come - there are according to the record but two beds of limestone so much as twenty feet thick and beds of half 
this thickness are few. At Keokuk, shales comprise threefifths of the Mississippian series. At Grinnell the proportion of limestone is but little greater than at Centerville. This change from limestone in the north to shales in the south has been noted by McGee who adduced the fact that the. Kinderhook is almost wholly shales at Burlington and almost wholly limestone at Marshalltown, Iowa Falls and Humboldt. But the completeness of this change as shown by the Grimnell and Centerville sections is as new as it is significant.

\section{DEYONIAN.}

No well section presents the probable maximum thickness of the entire Devonian series. If the Devonian is divided by means of the brecciated beds which extend from Scott at least to Fayette county with singular uniformity of position and persistence of character, there would be an upper and a lower member which meet and merge in the disturbed or brecciated beds. The dividing line lithologically and paleontologically also to a certain extent passes through their midst. As thus defined the lower Devonian is penetrated by three wells: Davenport, Cedar Rapids and Vinton. At Davenport the summit of the section is somewhat above the base of the brecciated portion. The thickness of the section here is 115 feet. At Cedar Rapids the total thickness of the lower Devonian appears to be a little over 100 feet. At Vinton the well head is probably somewhat below the Spirifera pennata beds of Calvin and the thickness of the well section is 250 feet. At Ackley the entire Devonian series was pierced, its thickness being 365 feet. At Mason City the Devonian has thinned to from 100 to 200 feet. At Washington, also, it is but seventy-four feet thick. The greatest thickness of the Devonian therefore probably lies to the west of 
Cedar Rapids and Vinton. The drillings from the lower Devonian at Davenport, Cedar Rapids and $V$ inton exhibit the same lithological peculiarities and are indistinguishable from the out-cropping rocks of the same horizon. A hard, drab, non-magnesian limestone with subconchoidal fracture compacted of the finest calcareous flour is highly characteristic of these beds. At Vinton and Cedar Rapids a buff magnesian limestone occur's which probably represents the lower buff magnesian limestone exposed at Otis. The non-magnesian beds have entirely passed out at Emmetsburg, if indeed any of the Devonian extends that far to the west.

\section{SILUTRIAN.}

Upper Division. Toward the north and west so far as determined the Upper Silurian preserves unchanged the characteristic qualities of its outcrop; remaining a hard, white gray, or buff, rough porous dolomite, often cherty and with obscure casts and moulds of fossils. At Vinton a thin vein or pocket or fine siliceous powder was struck but such residuary products are met in the country rock. The most interesting and important discovery made from well sections concerning the Upper Silurian is that of Calvin who found at Washington that it had lost its dolomitic character and had become a more or less calciferous sandstone. As such it continues to Keokuk and Centerville. To the west, as at Grinnell, it seems to retain its usual facies.

Special interest attaches to the thickness of the Upper Silurian in these sections on account of the estimates that have heretofore been made from its outcrop, these varying from 350 to 540 feet. At Davenport and Tipton the Upper Silurian section seems to reach its maximum thickness at 320 to 330 feet. At Tipton, perhaps the upper 
beds were not passed through, since at Mount Vernon, lying eighteen miles to the northwest, the same formation appears about 460 feet above the supposed base of the Upper Silurian at'Tipton. But this may be due to an anticline, as sixteen miles further to the west at Cedar Rapids it has thinned to 285 feet. At Vinton, Ackley and Mason City it is about 100 feet.

Maquoleta Shales. This formation forms so constant and unequivocal a member of well sections at least in the eastern part of the state that it is quite indispensible in their interpretation. Softer and paler than the shales of the Cambrian and more free from sand and more largely calcareons than the shales of the Coal Measures it is readily differentiated from most of the lithologically similar beds above and below it. Though deeply buried over most of the area under consideration it may possibly have in some locality an economic value as a cover to some unknown reservoir of natural gas or oil. The name sometimes applied by drillers, "mudrock shales," is forcible and appropriate. The calcareous element is large and in all samples tested is associated with more or less magnesia. Intercalated beds of limestone are rare, yet at Ackley two thin layers of magnesian limestone occur, and at $V$ inton there is a stratum of brown dolomite twenty-three feet thick, classed with the Maquoketa because of the fifty-four feet of shale that underlie it. Perhaps at both places these strata represent the Galena which is sometimes shaly and which is otherwise absent here. Near the base of the Maquoketa shale at Monticello highly bituminous layers occur. It often is in places highly pyritiferous, sometimes being colored black from this cause. At Tipton, its superior member is a gray argillaceous limestone. At Davenport, in the Kimball 12 G. Rep. 
House section, 125 feet of fossilferous argillaceous limestone underlie the Maquoketa and must be classed with it if its place in the record is correct.

The great thickness of these shales was quite unexpected, no previous estimate having exceeded 100 feet. But at Davenport, according to the Kimball House record, the shales are 242 feet thick. At Tipton they are at least 185 feet thick and may even reach 295 . At $V$ inton they are 258 feet, according to drillings, and are reported in the record of the second well at 320 feet. At Monticello they may reach 285 feet. Toward the east and west of this central area they become thinner, although they are 160 feet thick at Clinton and Ackley. At Mason City they are reduced to fifty-seven feet and at Emmetsburg to fifteen feet if represented there at all.

To the southwest they also thin out, at Washington being not more than 101 feet; at Keokuk sixty-three feet, and at Centerville absent or so thin as to escape notice. At Grinnell eighty feet of shale may be referred to this formation.

Galena-Trenton Limestones. These formations which in well sections often cannot be differentiated are of special interest from their possibilities in economic geology. Wherever the drill passes within these rocks it is followed with an expectancy born of the disclosures it has made in other states. In Ohio and Indiana, the lower Trenton is the source and the porous, creviced Upper Trenton, or Galena, the reservoir of the stores of natural gas and oil, whose recent discovery has made an epoch in the industrial history of the nation. CerCertain conditions of attitude, structure and lithology are necessary for the accumulation in commercial quantities of these precious illuminates, but whether or not these 
conditions exist in eastern Iowa is a matter of further investigation.

The evidence for the existence of gas and oil in these rocks throughout the state is as yet largely negative. Thus far no facts have been discovered tending to prove that the Trenton in eastern Iowa embraces any thickness or extent of bituminous shale. At one place only, Washington, was such found in this formation, though elsewhere it may be present but unrepresented in the drillings. Argillaceo-calcareous shales indeed oceur, and in greater volume than anywhere along the Trenton outcrop in Iowa. These are especially extensive to the north. At Emmetsburg they are ninety-five feet; at Mason City fifty-five feet, and at Ackley thirty-five feet thick. At the latter place, however, they are indurated and have the facies of the shaly layers of the Cambrian. These basal shales reappear only at Clinton and Centerville. Elsewhere the Trenton presents the lithological features which characterize it along its eastern outcrop. It is often fossiliferous, gray, bluish, or buff limestone, briskly effervescing with acid, never a dolomite, though usually containing more or less magnesia.

The Galena, the importance of which as a reservoir for oil and gas has been noticed, seems to preserve its identity and the structure which fits it for these uses, to long distances from its outcrop. As far south at least as Davenport and Tipton, and as far west as Cedar Rapids and Monticello, it remains unchanged. Further to the south and west, at Washington, and also at Ackley and at Vinton, no evidence of it appears. Yet, upon the western side of the Ackley-Vinton trough, the rising strata of this horizon again become magnesian limestones or dolomites, as seen at Mason City and Emmetsburg. At the extreme 
south, also at Centerville, the place of the Galena is occupied by a hard, buff, magnesian limestone or dolomite, which like the Upper Silurian becomes arenaceous.

Over the western part of the area under consideration the thickness of the Galena and T'renton is quite uniform, as from Mason City to Ackley it falls but little short of 400 feet, and exceeds this from Clinton to Davenport. Even as far west as Grinnell it.is 420 feet. To the south it thins, together with the other members of the Devonian and Silurian, though much less than they ; thus, at Washington it is 297 feet thick; at Sigourney and Keokuk less than 150 feet thick; and at Centerville 210 feet. At Monticello it is listed at but 225 feet. It probably extends, however, to the place of the last sample of the Maquoketa. This would add to it nearly 100 feet.

Saint Peter Sandstone. Whenever pierced by the drill the Saint Peter is found to remain the same bed of incoherent sand so often described in Iowa and adjacent states. Its grains are remarkably uniform in size in any locality and stratum, though they vary considerably in different places and sometimes in different strata in the same well section. At West Liberty, at a depth of 1,000 feet, the grains are .18 millimeters in diameter on the average. At Tipton most of the grains are included between .27 and .39 millimeters, the largest observed being 1 millimeter. At Cedar Rapids the larger number fall .37 and .55 millimeters; at Vinton and Ackley between .46 and .55 millimeters ; and at Emmetsburg between .46 and .64 millimeters. At Centerville there is a remarkable nearness of the large majority of grains to .36 millimeters.

A sample taken at random from the sandstone of the Saint Peter at McGregor showed more diversity in size of grains than is usually obtained in the artesian washings. 
In this sample most of the larger grains agree in size with those from Centerville, but there are many about .18 millimeters in diameter.

The grains from the drillings are of liquid quartz, well rounded through water movement and smoothed like groimd-g]ass, so that under the microscope they have a certain superficial whiteness, though this is not opaque enough to conceal the brilliant colors which the abraded crystals display between crossed nicols. No silt or cement is present; nor do the grains show secondary enlargement.

The moist sand in bottles is sometimes seen to redden with time next the glass with dull ferruginous stcins. The iron thus oxidizing is hardly native, but is probaty either due to the slightly ferruginated water of the well or to minute filaments and scales of iron from the drill and rods. Such is certainly the origin of the rusty cement sometimes joining a few grains together.

In thickness, the Saint Peter varies from forty feet at Centerville to $\mathbf{1 1 6}$ feet at Cedar Rapids. No law is found governing this increase. A group of wells, where it is thinnest, as at Monticello, West Liberty, Vinton and at Tipton where it cannot be over fifty-five feet, are divided by the maximum thickness at Cedar Rapids. And though it reaches its minimum at Centerville it is remarkably uniform in the other wells of 'southeastern Iowa, not varying in them over ten feet from 100 feet. In the northwest the range of the Saint Peter is nearly the same as in the extreme southeast, it being eighty-five feet thick at Mason City and 110 feet at Emmetsburg. These variations are slight compared with those described in parts of Wisconsin, and where owing to the irregular surface of the Oneota on which the sands were spread the Saint Peter 
thins out completely on the folds of the inferior limestone, and thickens in its troughs to 212 feet.

The relation of the Saint Peter to sea level is seen in the accompanying diagrams (plates xvii and xviii) which illustrate some facts of interest. An eastward dip of the Paleozoic of northeastern Iowa is clearly seen in the section from Emmetsburg to Mason City. Where the section runs parallel to the strike of the geological formations, little change in level of the Saint Peter occurs; where it crosses the strike at an angle, the general southerly dip is usually noticed. Some significant exceptions occur; as for example, on the section from Tipton to Cedar Rapids (omitting intervening points). At the latter point the Saint Peter should be found at a lower level than atTipton. But the Cedar River deformation, noticed by McGee, seems to have here lifted the sandstone to seventy-three feet above its level at Tipton. The dip is also anomalous on the entire section from Davenport to Ottumwa. In all this distance the Saint Peter seems to have declined but very little.

Oneota Limestone. Drillings from horizons beneath the Saint Peter have well-marked characteristics which readily distinguish them from drillings from any superior formation. But the difficulties already mentioned in passing from the finely comminuted and heterogeneous drillings to the rock of which they are in part composed apply here with peculiar force, when there is an attempt to discriminate the different formations of which this complex is composed. Even in the field, with plentiful outcrops and quarry sections, it sometimes is not very easy to delimit formations that graduate vertically into one another. How much harder then when the only data are artesian drillings! Other 


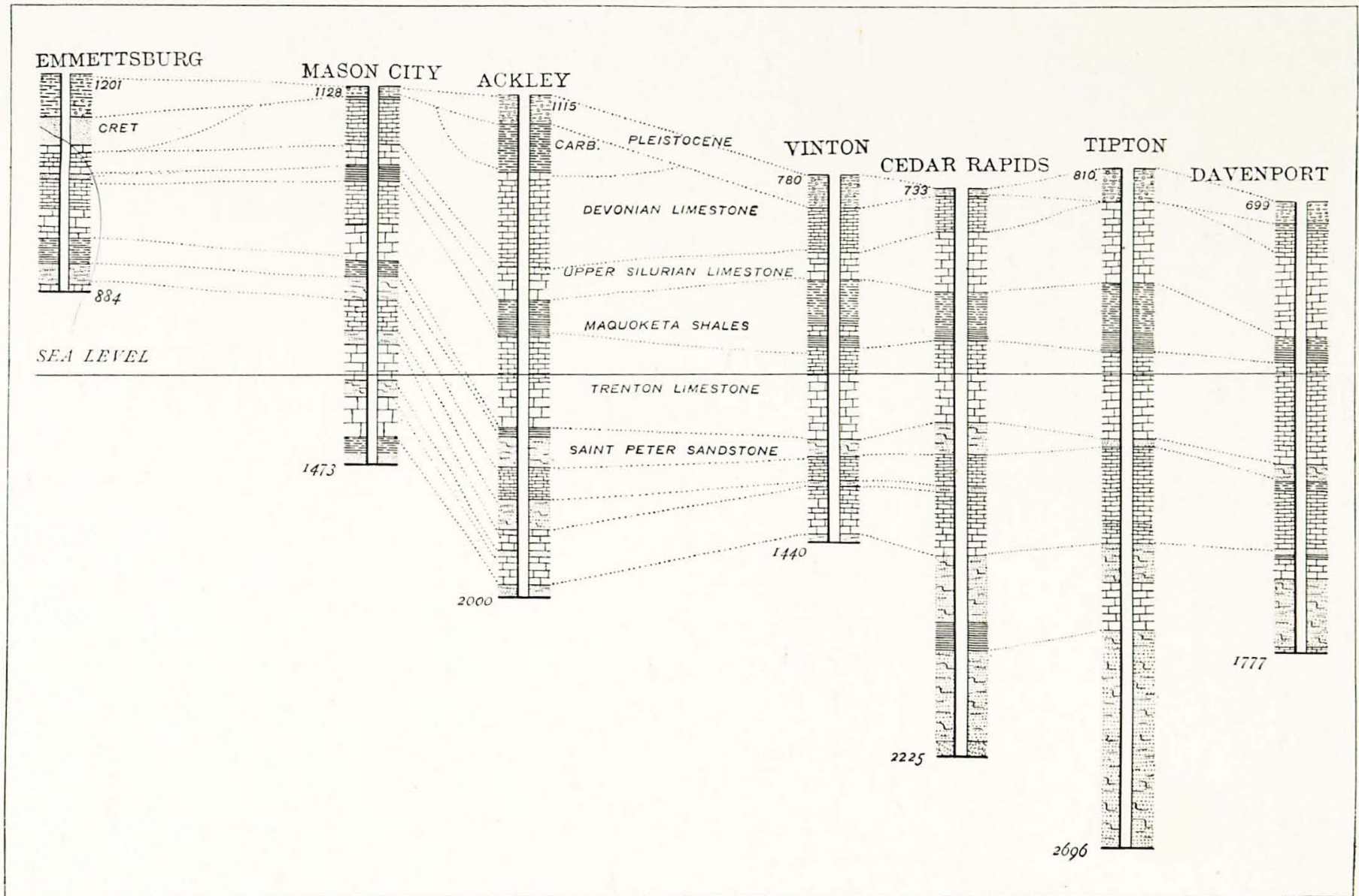

DEEP WELL SECTIONS FROM EMMETTSBURG TO DAVENPORT. 

difficulties arise when an attempt is made to correlate members of sections widely distant, belonging to a rock series whose members may be variable horizontally ; arenaceous shales, for example, passing into sandstones on the one side and arenaceous limestones on the other. Add to this the fact that no limestone, shale, or sandstone of this series possesses any known features which in artesian drillings surely distinguish it from any other limestone, shale or sandstone of the same series, and it will be seen that no claim for inerrancy can be made for any conclusions that may reach any such methods.

Nevertheless the various well sections set forth a few salient facts in which there can hardly be any large per cent of error. Immediately underlying the Saint Peter sandstone, though sometimes as at Ottumwa and Davenport, separated from it by a transition bed of arenaceous, slaty shale, there occur every where in eastern Iowa heavy beds of dolomite. These are in whole or in part the extension of dolomites of the Upper Mississippi, ealled the Lower Magnesian by Owen and the Oneota by McGee. In places, as at Tipton and Cedar Rapids, these dolomites are undivided so far as the ineomplete records show, but elsewhere they are bipartite, being separated into two beds by a layer of sandstone. This intervening sandstone thins to the northeast and thickens to the west and sonth. At Monticello it may be no more than 15 feet thick and at Vinton it is 20 feet thick; at Cedar Rapids and Tipton it obtained no recognition from the drillers. At Ackley it is 80 feet thick; at Mason City 50 feet; at Grimell 85 feet thick; at Ottumwa 122 feet; at Centerville 130 feet, and if calciferous passage beds with the upper dolomite be added, it is here 235 feet thick. 
Meanwhile the dolomitic bed above this sandstone maintains a remarkable regularity in thickness from Mason City to Centerville. The lower dolomite is more variable, and to the south more massive. At Centerville it is at least 370 feet in thickness and it is reported to be 697 feet thick at Ottumwa. These dolomitic beds may be designated as the upper and lower Oneota and the intercaleated sandstone as the New Richmond. The upper and lower Oneota are so alike in structural and lithological features, as appearing in drillings, that it is unnecessary to separate them in description further than to state that the lower division is on the whole more arenaceous. Each is a crystalline or subcrystalline dolomite, usually gray or white in color, but sometimes buff. So hard is the rock that chips large enough to indicate its structure are seldom procured. Occasionally it is seen to be porous or to carry minute imbedded grains of quartz. Much of the sand present in its drillings is no doubt from above, but much is also native, either disseminated or interstratified. The larger part of the silica of the Oneota is in the form of chert or flint, flakes of these minerals often forming a large part of the drillings and seldom or never wholly absent.

Drillings from the horizon referred to in New Richmond sandstone present no special diagnostic features to distinguish them from inferior sandstones. Usually in variation in size of grain and in proportion of fine quartzose matter, it resembles the sandstones beneath it. At the base of the Ackley section it strongly resembles the Saint Peter.

\section{CAMBRIAX.}

Saint Croix. Wherever, in eastem Iowa, the drill perforates the lower Oneota, it reaches a sandstone whose thickness varies considerably, from fifty-eight feet at 
IOWA GEOLOGICAL SURVEY.

PLATE XVIII.

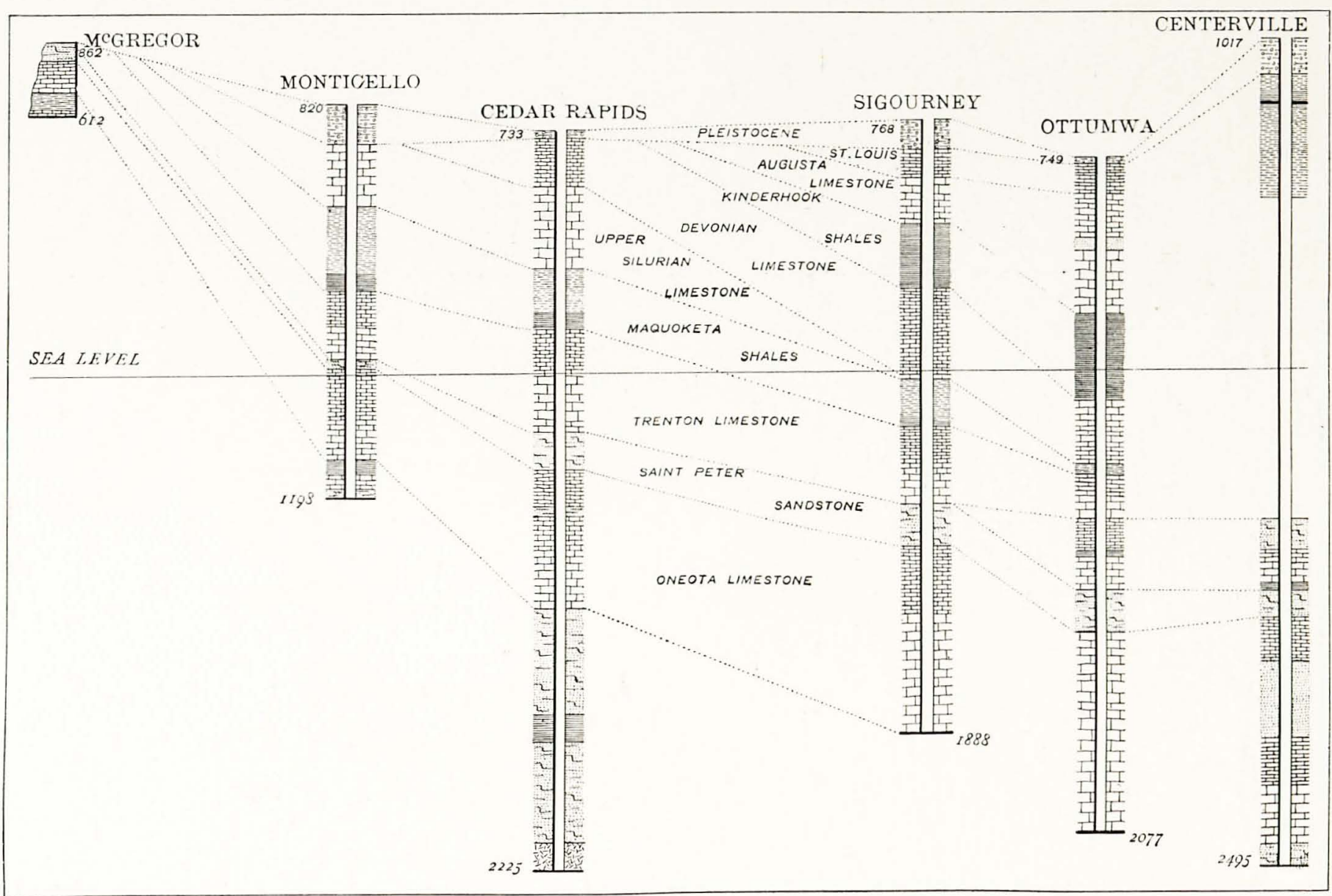

DEEP WELL SECTIONS FROM MCGREGOR TO CENTERVILLE. 
Monticello, where, however, the drill may not have reached its base, to perhaps $15 \pm$ feet at Tipton, and 165 feet at West Liberty. Beneath this sandstone the deeper borings disclose dolomites, somewhat thin and inconstant compared with the Oncota, and heavy beds of shale. At Tipton this formation is composed of dolomites estimated a eighty-five feet thick, resting on 100 feet of arenaceous shale. At Cedar Rapids $\mathbf{1 0 0}$ feet of shale pass upward through calciferous sandrock into the sandstone just mentioned. At Mason City, 116 feet of limestone overlie fifty-eight feet of shale. The upper member, the sandstone, may be termed the upper Saint Croix and the lower member, the dolomites and shales, the lower Saint Croix.

The lithological affinities of the upper Saint Croix sandstone are with the Potsdam, as defined in this paper. As delimited in the sections, it is often more or less caleiferous, and sometimes the dolomitic phases graduate upward into the lower Oneota and downward into the lower Saint Croix. At Ackley these transition beds are especially noteworthy. Perhaps here the main body of sandstone was not reached. Its colors are the lighter tints, gray, yellow and buff.

The dolomites of the lower Saint Croix do not differ lithologically from other dolomites of the magnesian series. They pass beneath into shales and sandy beds. At Cedar Rapids the argillaceous element prevails, the dolomites and silicous elements being insignificant. At Mason City and Tipton the latter elements are in excess of the former. The shales are of a decided green tint, usually bright and rather dark.

The sandstone below the lower Saint Croix differs from the Saint Peter in the wider diversity in size of grains, in fineness of grains of some of its beds and in 
its greater induration, as shown by faceted grains and the rarity of unfractured grains of any considerable size, the rule obtaining here, as elsewhere, that the harder the rock the smaller the fragments into which it is broken by the drill. In color it ranges from white to pale yellow, pink and buff, not reaching, where observed in Iowa, the darker shades of red and brown.

At only two points in eastern Iowa, at Cedar Rapids and Tipton, are there records of the strata beneath the basal shales of the lower Saint Croix; at Cedar Rapids 360 feet of sandstone which overlies the Algonkian floor, and at Tipton 443 feet of sandstone below the basal shales are referred to the horizon in question.

\section{ALGONKIAN.}

To the Sioux quartzite belongs the seventy-five feet of vitreous quartzite which forms the base of the Cedar Rapids section. On comparing the Tipton section it seems best to consider the 451 feet of its basal sandstones, all more or less indurated as indicated by their faceted grains and the fine, angular fragments into which the rock was broken by the drill, as the eastward extension of the same beds. The drillings examined furnished no proof that the Algonkian has been elsewhere reached.

DRILL RECORDS OF DEEP WELLS IN EMMETSBURGDAVENPORT SECTION.

\section{Emmetsburg Well.}

( Elevation sor feet abore sea level.)

THICKNESS. DEPTH.

18. Soil ............................. 5

17. Clay, bright yellow, calcareous with drift pebbles, Upper Till............... $16 \quad 21$

16. Clay, blue, pebbly, more strongly calcareous than No. 17, Lower Till........... $204 \quad 225$ 
THICKNESS. DEPTH.

15. Sand, moderately coarse, gray, mostly clear quartz, but many grains of pink and dark gray quartz, jasper and flint ......... 30

14. Sand, very coarse, similar in composition to No. 15, fragments also of fine white kaolinic clay................... 79

13. Clay, fine, bright red, a trifle sandy, noncalcareous ..................... $22 \quad 356$

12. Dolomite, hard, subcrystalline, fossiliferous, in gray and buff cubes.......... $10 \quad 366$

11. Dolomite, or magnesian limestone, buff, hard, rough, sub-crystalline, with considerable sand $\ldots \ldots \ldots \ldots \ldots \ldots \ldots \ldots \ldots, 22 \quad 3^{88}$

10. Shale, blue................... $4 \quad 392$

9. Sandstone, coarse grained, with small pebbles identical in composition with Nos.

If and $15 \ldots \ldots \ldots \ldots \ldots \ldots \ldots \ldots \ldots$ 30 422

8. Shale, light blue................ $15 \quad 437$

7. Limestone, magnesian, gray.......... 50 487

6. Dolomite, light buff, soft............. go 577

5. Magnesian limestone, hard, gray.................. 84

4. Shale, blue, argillaceous ............. $65 \quad 726$

3. Shale, as above, dark blue .......... 30 $75^{6}$

2. Sandstone, presenting all the characteristics of the Saint Peter; grains mostly between .55 and .70 millimeters............ $110 \quad \$ 66$

I. Dolomite, light gray, subcrystalline, termed in drillers' record "granite "... $18 \quad 884$

The total thickness of the Pleistocene ( 16 and 17 ) is 220 feet. Numbers 13, 14 and 15 are probably Cretaceous ; 12 is a coarse, rough dolomite unlike, lithologically, any Creta- . ceous rocks in Iowa, and contains a fragment of an impression of one valve of a square-shouldered brachiopod unmistakably Paleozoic. The Chicago, Milwaukee and Saint Paul Railway Company contributed a tube of drillings which correspond exactly, in the drillings and in the accompanying record, so far as it is preserved, with the Emmetsburg section.

As 2 is plainly the Saint Peter, 3 and 4 may be referred to the Trenton and one to the upper Oneota. 


\section{Mason City Well. (Elevation 1128 feet above sea level.)}

THICKNESS. DEPTH.

19. Black loam................... 2

18. Clay ........................... $26 \quad 28$

17. Limestone, brown, soft, argillaceous...... 7o 98

16. Dolomite, hard, light bluish gray, granular, subcrystalline with some lighter and softer briskly effervescent limestone.... II 9

I5. Dolomite, or magnesian limestone, hard, brown....................... $87 \quad 304$

14. Shale, blue.................... $57 \quad 3^{61}$

13. Limestone, magnesian, hard, pale buff.... 50 4tr

12. Limestone, magnesian, flinty, impure, bluish gray with earthy lustre.......... $300 \quad 71 \mathbf{I}$

II. Shale, green, slightly gritty, with chert and particles of magnesian limestone...... $55 \quad 766$

10. Dolomite, highly arenaceous; yellow..... $20 \quad 786$

9. Sandstone, fine, white, grains rounded and ground $\ldots \ldots \ldots \ldots \ldots \ldots \ldots \ldots \ldots \ldots \ldots, 85 \quad 874$

8. Dolomite, white................. I13 984

7. "Mixed lime and sandstone" (no sample). 50 1034

6. Dolomite, light gray............... I47 1179

5. Sandstone, buff and white ........... $60 \quad 1249$

4. Dolomite, hard, gray, with flakes of rather hard, green shale................ $116 \quad 1365$

3. Shale, greenish, highly arenaceous, with fragments of dolomite............ $5^{8}$

2. Sandstone, gray, larger grains, rounded, many smaller angular fragments, with some greenish shale.

1. "Granite." The sample so labelled consists of sandstone similar to 2 , rounded grains about $.25-35$ millimeters in diameter, with some dolomite, chert and shale. None of the constituents of granite are present except quartz......... $5 \quad$ I473

NUMHERS.

17-19. Humus and drift $\ldots \ldots \ldots \ldots \ldots \ldots \ldots \ldots \ldots, 28$

15-17. Devonian and Upper Silurian................ 276

14. Maquoketa......................... 57

11-13. Galena-Trenton........................ 405

9-10. Saint Peter . . . . . . . . . . . . .

6-8. Upper Oneota.......................... 308

I. Algonkian (penetrated) $\ldots \ldots \ldots \ldots \ldots \ldots \ldots \ldots \ldots \ldots$ 
The mixture of drillings in 16 and the absence of definite criteria make it impossible to delimit the Devonian and upper Silurian ; 12 shows drillings consisting mostly of flint, which cannot, of course, represent the true charter of rocks aggregating 300 feet. Though no "granite" occurs in 1, the driller's record may be relied upon that the Algonkian quartzite was reached at this point.

\section{Ackley Well.}

(Flevation 115 feet above tile.) DEPTH.

S7. Alluvium or drift. . . . . . . . . . . . . . . .

S6. Shale, fine, blue................... 100

$8_{5}$. Shale, fine, blue....................... $\quad 1_{15}$

84. Sandstone, coarse, buff, vesicular........... ${ }_{35}$

8 . Shale, fine, blue $\ldots \ldots \ldots \ldots \ldots \ldots \ldots \ldots \ldots \ldots$ 140

82. Shale, fine, blue $\ldots \ldots \ldots \ldots \ldots \ldots \ldots \ldots \ldots \ldots$ 150

81. Sandstone, fine, bluish white............. $16_{3}$

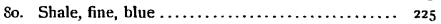

79. Shale, fine, blue $\ldots \ldots \ldots \ldots \ldots \ldots \ldots \ldots \ldots \ldots .249$

78. Shale, fine, blue $\ldots \ldots \ldots \ldots \ldots \ldots \ldots \ldots \ldots \ldots \ldots{ }^{250}$

77. Sandstone, as No. 82.................. 260

76. Shale, blue, white, ferruginous, with concretions.. 265

75. Shale, fine, blue $\ldots \ldots \ldots \ldots \ldots \ldots \ldots \ldots \ldots \ldots \ldots, 290$

74. Limestone, magnesian, highly pyritiferous, containing a little chert................. 307

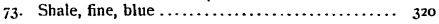

72. Limestone, dark gray, magnesian.......... 335

71. Limestone, argillaceous, non-magnesian, with a fragment of Atrypa reticularis, Linn......... 400

7o. Limestone, light yellowish gray, argillaceous, slightly magnesian, with some green shale.... 410

69. Limestone, light bluish gray, non-nagnesian.... 460

68. Limestone, light yellowish gray, argillaceous and slightly siliceous................... 473

67. Limestone, blue, agillaceous, non-magnesian.... 500

66. Limestone, blue, argillaceous, slightly magnesian. 555

65. Limestone, brown, slightly magnesian........ 570

64. Limestone, brown, slightly magnesian......... 600

63. Limestone, brown, slightly magnesian......... 6to

62. Limestone, light brown, magnesian......... 635

61. Dolomite ........................ 730

59. Dolomite, with much chert ............... 735

5. Dolomite, with much chert $\ldots \ldots \ldots \ldots \ldots \ldots \ldots, 740$ 
57. Dolomite, with much chert $\ldots \ldots \ldots \ldots \ldots \ldots \ldots$ 750

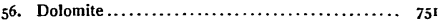

55. Dolomite $. . \ldots \ldots \ldots \ldots \ldots \ldots \ldots \ldots \ldots \ldots \ldots \ldots, 757$

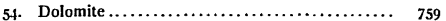

53. Dolomite............................ 760

52. Dolomite........................... 764

51. Dolomite, with chert................. 775

5o. Dolomite, with chert................. 787

49. Dolomite, with green shale............ 797

48. Dolomite, with green chert............... Soo

47. Dolomite, with green chert................ So3

46. Shale, green, samples of this from $\mathrm{S}_{5} 5$ to 960 feet. A hard, brown dolomite, crystalline, cherty, occurs at 875 and 896 feet, thus being interbedded in the shale ...................... 960

45. Limestone, light gray, cherty............. 975

44. Limestone, light gray, cherty............. 995

43. Limestone, light gray, soft............. 1015

42. Limestone, light gray, darker.............. 1040

41. Limestone, light gray $\ldots \ldots \ldots \ldots \ldots \ldots \ldots \ldots \ldots$ 10

40. Limestone, light gray, softer............. 1100

39. Limestone, light gray, softer.............. $115^{0}$

38. Limestone, soft, light gray, with some darker bluish gray....................... 1160

37. Limestone, light gray................. 1180

36. Limestone, light bluish gray, fossiliferous...... . 1205

35. Limestone, light bluish gray, fossiliferous....... 1230

34. Limestone, light bluish gray, fossiliferous....... $123^{8}$

33. Limestone, light buff.................. 1250

32. Limestone, dark gray ................ 1257

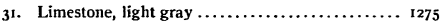

30. Limestone, drillings are a fine, bluish black, calcareous sand mixed with some of lighter color, highly pyritiferous, considerable argillaceous material and many miscroscopic particles of quartz 1300

29. Limestone, bluish gray, fossiliferous.......... 1320

28. Shale, green ........................ 1325

27. Shale, bright green, indurated, slaty, highly pyritferous............................. 1335

26. Shale, bright green, slaty .............. 1350

25. Sand, white grains, rounded, somewhat uniform in size............................. 1360

24. Sand, white grains, rounded, somewhat uniform in size............................ 1405 
23. Sand, white, grains rounded, somewhat uniform in size, finer............................ 1415

22. Limestone, white, subcrystalline............ 1445

21. Dolomite, in fine, light yellow powder ......... 1448

20. Dolomite, with considerable light green shale... 1490

19. Dolomite, buff, with shale and ocherous grains... 1500

18. Dolomite, white, with some chert and quartz and green shale......................... 1505

17. Dolomite, white, with some chert, quartz and green shale.......................... 1515

16. Dolomite, light yellow .................. $153^{\circ}$

15. Dolomite. hard, gray, subcrystalline, with grains of quartz............................. 1540

14. Dolomite, white ..................... 1548

13. Dolomite, hard, rough, light buff, subcrystalline.. $155^{\circ}$

12. Sandstone, white, rounded grains, with numerous minute chips of dolomite................. 1565

11. Sandstone, as above.................... 1580

Io. Sandstone, light, fine grained, friable, grains rounded, varying widely in size, the largest being about one millimeter in diameter....... 1595

9. Sandstone, hard, light gray, moderately fine grained, with considerable green shale. ....... 1610

8. Sandstone, white, grains rounded and resembling the Saint Peter in general uniformity in size; many from seven to nine millimeters, largest over one millimeter..................... 1635

7. Dolomite, buff........................ 1645

6. Dolomite, arenaceous or calciferous sandstone.... 1675

5. Dolomite, hard, gray, subcrystalline, pyritiferous. 1685

4. Dolomite, light gray .................... 1720

3. Dolomite, siliceous, gray, with admixture of quartz grains, and some chert................. 1820

2. Dolomite, like above, but with more chert....... 1950

I. Sandstone, grains rounded, moderately large, with considerable gray dolomite................ 2000

73-86. Coal Measures......................... 235

62-72. Devonian.............................. 365

47-61. Upper Silurian.......................... 115

46. Maquoketa ............................ 160

26-45. Upper and Lower Trenton.................. 385

23-25. Saint Peter $\ldots \ldots \ldots \ldots \ldots \ldots \ldots \ldots \ldots \ldots \ldots \ldots . \quad 85$

13. Oneota $\ldots \ldots \ldots \ldots \ldots \ldots \ldots \ldots \ldots \ldots \ldots \ldots \ldots \ldots \ldots \ldots \ldots \ldots, 375$

I- 3. Upper Saint Croix (penetrated )............. 28o 
Numbers 73-86 are taken to represent a Carboniferous outlier rather than the Kinderhook. With the interealated magnesian limestone in 46 , there should be compared the similar bed interstratified with the Maquoketa shales at $V$ inton. In each instance it is possible that these beds represent the westward extension of the Galena. 26, 27 and 28 are transition beds from T'renton to Saint Peter, and into the latter 26 and 27 should perhaps be placed. Perhaps 22 represents a calcareous layer near the base of the Saint Peter. 1, 2 and 3 represents the passage beds from the lower Oneota to the upper Croix, growing more and more arenaceous downward, but remaining more or less calciferous to the bottom of the well. In this well, as in others, where the specific depth of each sample is stated, it is assumed as a general rule in reckoning the thickness of a stratum, that the drillings represent its summit and that it extends beneath to the portion of the next drillings.

IV. Vinton Well No. 1 . (Elevation 780 above tìde.) THICKNESS. DEPTH.

36. Alluvial and Drift deposits, in ancient river

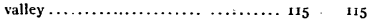

35. Limestone, chips hard and compact, nonmagnesian, light cream color, fracture sub-conchoidal .................. 20

34. Limestone, chips magnesian, light buff, porous, subcrystalline............. I5 150

33. Limestone, powder pinkish, argillaceous, cherty, contains some magnesia ; associated with some dark clay and light nonmagnesian limestone................ $18 \quad 168$

32. Limestone, powder white, non-magnesian, pyritiferous, with white chert and some rounded grains of quartz........... $82 \quad 250$

3t. Dolomite, hard, compact, sub-crystalline, yellowish in color, with white chert, inclosing centres of gray flint........ $15 \quad 265$ 
THICKNESS. DEPTH.

3o. Dolomite, powder white.

29. Dolomite, bluish gray, subcrystalline, with gray flint..................... 10 $\mathbf{2 S}_{5}$

2S. Clay, light green.................. $5 \quad 290$

27. Sandstone, very fine, white, grains angular........................... 5

26. Dolomite, chips soft, light gray, porous, subcrystalline, with a little dark gray flint. 55

25. Shale, green, calcareous

24. Shale, fine, bluish, calcareous, soluble portion magnesian. ................. 167

23. Magnesian limestone or dolomite, chips hard, brown, subcrystalline, ferruginous 23

22. Shale, light and dark gray............

20. Limestone, powder light gray, argillactuus, contains some magnesia ........... I I

19. Limestone, powder cream colored, contains some magnesia................. $3^{0}$

760

$7^{\text {So }}$

IS. Limestone, as above $\ldots \ldots \ldots \ldots \ldots \ldots \ldots$. 20

17. Limestone, as above $\ldots \ldots \ldots \ldots \ldots \ldots \ldots .27$

16. No sample....................

15. Limestone, like No. 19, gray in color...... I

14. Limestone, chips minute, soft gray...... $6_{5}$

13. Limestone, chips minute, bluish gray, nonmagnesian..................... 75

12. Limestone, chips thin, flaky, rather soft, fine grained, compact, light gray, nonmagnesian..................... 45

11. Sandstone, with fragments of limestone... 20

10. Sandstone, clean quartz, grains rounded, of moderate and nearly uniform size, vitreous, limpid, surface ground .......... 35

9. Chert, white, with white dolomite, and greenish slate-like shale.............

8. Dolomite, chips subcrystalline, minutely porous, medium dark gray, with much chert....................... 15

7. Dolomite, powder fine, white........... 807 820 $8_{35}$ 900 975 1020 1040

6. Dolomite, chips white and light gray, fine grained, subcrystalline, with some chert.

5. Dolomite, hard, medium dark gray, and softer white. 
THICKNESS. DEPTH.

4. Sandstone, with considerable dolomite, grains of silica light colored, varying widely in size, largest being about .9 millimeters in diameter............ $15 \quad 1190$

3. Dolomite, like No. 6............. $85 \quad 1275$

2. Chert, with minute calcareous fragments.. io $\mathbf{1 2 8 5}$

1. Sandstone, grains mostly rounded varying considerable in size, largest about one $\begin{array}{lll}\text { milimeter, also considerable dolomite... } & 2 & 1287\end{array}$

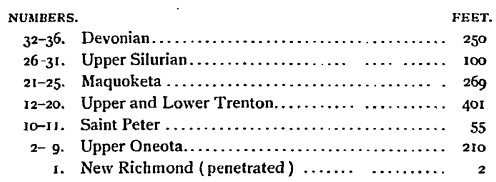

As the ancient river valley whose depth is represented in 38 is excavated in Devonian strata, the thickness of the Devonian penetrated is reckoned to the well-head. The following drillers' record is of a second well at Vinton bored to a depth of 1,440 feet or more :

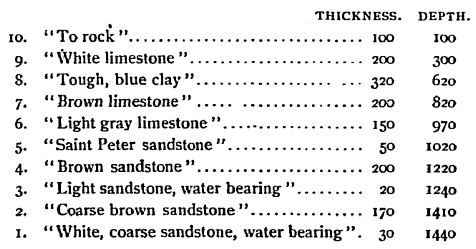

The agreement of the above record with the record and and drillings of well No. 1 is more noticeable than the disagreement between them. The discrepancies in the records of the two wells are as follows: In well No. 2 the 
Upper Silurian is not discriminated, the top of the Maquoketa is fifty feet higher than in the record of well No.1; the Maquoketa is fifty-two feet thicker and the Galena-Trenton as much thinner; the Upper Oneota is called "brown sandstone," tlie drillers not distinguishing the fine sand of angular drill-cut fragments of dolomite from true silicious sand, a common error. The thickness of the Saint Peter is the same in both sections, but it is placed fifty fect higher in well No. 2. The thin sandy layer at 1,175 in well No. 1 is overlooked in well No. 2. Sandstone 3 of well No. 2 is identical with the basal sandstone of well No. 1 , and is referred to the New Richmond; 2 of well No. 2, 170 feet thick, is taken to be the lower Oneota dolomite and 1 to be the summit of the upper Saint Croix sandstone.

T. Cedar Rapids Well, No. 1. (Ellevation 733 feet above tide.)

THICKNESS. DEPTH.

26. Alluvium ................... to

25. Limestone, light buff, rather soft, magnesian ; and gray, very hard, non-magnesian, compact, somewhat fragmental in structure...................... 40 50

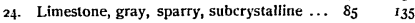

23. Limestone, moderately hard, light buff, magnesian.. ................... 40 $\quad 175$

22. Dolomite, pink, minutely vesicular, subcrystalline ...................... $65 \quad 240$

21. Dolomite, bright buff, porous.......... $60 \quad 300$

20. Dolomite, hard, light gray, porous....... 30 330

19. Dolomite, coarser grained than above, light yellow in color............... $20 \quad 350$

18. Dolomite, hard, light gray, subcrystalline, with some white chert ............... $25 \quad 375$

17. Dulomite, like above but softer and yellowish in color ..................... $45 \quad 420$

16. Shale, fine, bluish green, calcareous, magnesian......................... $200 \quad 620$

15. Limestone, magnesian and non-magnesian. $295 \quad 915$ 
THICKNESS. DEPTH.

14. Shale.

5920

13. Sandstone, slightly bluish ór greenish gray. grains of quartz rounded, with considerable calcareous powder and some gray shale.

12. Shale, dark colored................. I 986

II. Sandstone, clean, white grains, rounded and somewhat uniform in size........ 50 $\quad 1036$

Io. Dolomite, light gray, rather hard, arenaceous, of fine texture, and with much finely laminated green shale............... 74

9. Dolomite, very hard, gray, subcrystalline.

8. Dolomite, gray, with chert, white and

quartzose sand $\ldots \ldots \ldots \ldots \ldots \ldots \ldots \ldots .270 \quad 1420$

7. Sandstone, drillings consist of fine white rounded grains with much finely comminuted quartz and many small angular fragments of white dolomite...........

6. Sandstone, fine, yellowish, water bearing..

5. Sandstone, with slight admixture of calcareous powder..................

4. Shale, tough and hard, containing a small amount of very fine silicious particles and some dolomite............. $100 \quad 1790$

3. Sandstone, light, reddish grains largely angular, some with crystalline facets... $160 \quad 1950$

2. Sandstone, cream colored, very fine grained....................... 200

1150

$\ldots$

. Quartzite, reddish brown, grains angular, rock drilled with great difficulty $\ldots \ldots \ldots \quad 75$

1690

Limestone of number 25 resembles the magnesian limestone outcropping beneath the Otis beds at water level along the Cedar river from Otis to Cedar Rapids. The well head lies somewhat above the Independence shales. Number 24 apparently occupies the place of the Bertram beds which they resemble lithologically; 23 is probably the Mount Vernon beds and the dolomites immediately subjacent, the Le Claire; 15 comprises the Galena and Trenton. In the drillers' record it appears as a "reddish 
brown sandstone." Three different sample drillings of this number each stated to represent the entire 295 feet, in the possession of different persons, illustrate the need of constant caution in dealing with such data. One sample is a gray dolomite, evidently from the Galena ; one a light gray, non-magnesian limestone, as surely from the Trenton, and the third is a quartz sand whose true position is quite uncertain. From the reaming of the well authentic samples of the Trenton were obtained at 800 feet and 850 feet. These consisted of chips of light gray, fossiliferous limestone, briskly effervescent in cold dilute hydrochloric acid lustre earthy, relieved by a few crystalline facets. The Trenton must, therefore, extend upward at least to 800 feet and occupy 120 feet of the 295 feet referred conjointly to it and the Galena; 7 appears to be the transition beds between the Oneota dolomites and the upper Saint Croix sandstones, and is classed here with the latter.

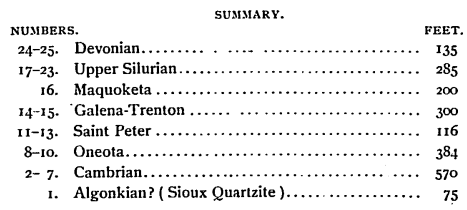

\section{Tipton Well.}

(Elevation 8ro feet above tide.)

DFPTH OF

54. Drift ......................... 125 125

53. Dolomite, hard, light gray, with white chert. $325 \quad 135$

52. Limestone, soft, medium dark gray, argillaceous, slightly magnesian........... 445

51. Shale, greenish .................

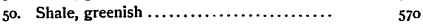

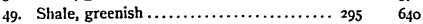


THICKNESS. DEPTH.

48. Dolomite, hard, gray ............. 60 . 740

47. Limestone, soft, light buff, magnesian..... 800

46. Limestone, soft, light gray, somewhat argillaceous...................... 850

45. Limestone, white, slightly magnesian ..... $\quad 885$

44. Limestone, soft, light gray, slightly magne$\operatorname{sian} . . . \ldots \ldots \ldots \ldots \ldots \ldots \ldots \ldots \ldots . \ldots \ldots$

43. Limestone, as above, but darker........ $95^{\circ}$

42. Limestone, dark bluish gray, fossiliferous, somewhat argillaceous, non-magnesian. . 150990

41. Shale, green ................. I5 1000

40. Limestone, soft, dark bluish gray, argilla-

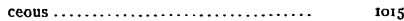

39. Limestone, as above $\ldots \ldots \ldots \ldots \ldots \ldots \ldots$ is 1030

38. Sand, clean, white, grains rounded and ground..................... $15^{-55} \quad 1_{70}$

37. Dolomite, hard, gray, with green shale.... $\operatorname{loS}_{5}$

36. Dolomite, white, in powder with considererable aluminous admixture and with minute grains of silicious sand........

35. Dolomite, in minute angular fragments, subcrystalline, light buff............. $\quad 1140$

34. Dolomite, light gray................ 1150

33. Dolomite, white, in powder........... Ir 55

32. Dolomite, gray, in coarser powder....... tiso

35. Dolomite, hard, gray............... 1195

3o. Dolomite, hard, lighter gray, with green shale........................ 1220

29. Dolomite, as above, cherty........... 1250

28. Chert, white, with minute fragments of dolomite, hard, gray, porous........ $377 \quad 1362$

27. Sand, fine, light-colored grains of rounded quartz, many with fresh fractured surfaces, some displaying crystalline facets, also many grains of dolomite, white, sub-

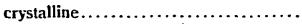

26. Sand, as above, but finer, with less dolomite......................... 154

25. Dolomite, dark gray.............. 86 1616

24. Shale, dark greenish, pyritiferous, with much dolomite, and fragments of finegrained argillaceous sandstone........ 100

23. Sandstone, white, grains angular and rounded, many faceted.............. 
THICKNESS. DEPTH.

22. Sandstone, as above. $186_{5}$

2I. Sandstone, white, grains very fine, mostly angular

1900

20. Sandstone, pinkish, fine-grained, in minute loosely coherent fragments.

1990

19. Sandstone, in fine reddish powder consisting mostly of microscopic grains of

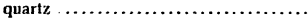

2100

18. Sandstone, in fine powder, gray, consisting, as seen under the microscope, of grains of quartz, mostly angular.

17. Sandstone, white, grains of moderate size, mostly angular, some with seconclary enlargements.................. 443

16. Sandstone, pinkish $\ldots \ldots \ldots \ldots \ldots \ldots \ldots \ldots$.

15. Sandstone, reddish................ 2300

14. Sandstone, pinkish, angular grains and grains with crystalline facets......... 2400

13. Sandstone, light pink, in angular fragments. $243^{\circ}$

12. Sandstone, reddish................. 2500

11. Sandstone, as above, but lighter in tint.... $255^{\circ}$

Io. Sandstone, reddish brown............ $\mathbf{2 5 7 5}$

9. Sandstone, dark reddish brown, grains angular..................... $\quad 2600$

8. Sandstone, fine-grained, brown......... 2630

7. Sandstone, fine-grained, reddish......... 2640

6. Sandstone, as above................. 2650

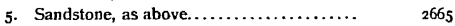

4. Sandstone, as above............... 2675

3. Sandstone, in very fine pink sand........ 2685

2. Sandstone, fine brownish............. 2696

I. Sandstone, very fine, light reddish brown., 451/2 $2696 \%$

SUMMARY.

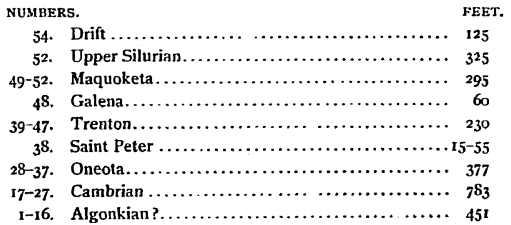


Drillings of numbers 1 and 16 consist of quartzose sand or powder composed of angular fragments, though all are termed sandstone above, the degree of induration of the rock may reach that of quartzite.

\section{Davenport, Park Well.} Elevation about 799 feet above tide.

THICKNESS. DEPTH,

26. "Loess," no sample ............... 40

25. "Boulder clay," no sample........... 60

24. Shale, dark, no sample ............. 30 130

23. Limestone, pure, hard, gray, compact, of fine texture, non-magnesian.......... $220 \quad 35^{\circ}$

22. Dolomite, hard, highly vesicular, light pinkish buff, with casts of crinoid stems, and casts of apex of Platystoma niagarense, Hall...................... 3

2I. Dolomite, subcrystalline, cream colored, highly vesicular, with obscure cast of bryozoans .................... 20

20. Dolomite, hard, bluish gray, subcrystalline. 90 490

19. Shale, lead colored, argillaceous, very slightly calcareo-magnesian, fossiliferous, blackens in closed tube, B. B., turns white.......................

8. Dolomite, white, arenaceous.......... 80

17. Dolomite, hard, gray, subcrystalline..... 50

16. Dolomite, hard, rough, brownish white, some fine gray shale.............. 75

15. Dolomite, lighter in color, with obscure casts of fossils referred to Zygospira.... 50

14. Dolomite, light brownish ............. 125

13. Dolomite, as above, with white chert.... 50

12. Dolomite, magnesian limestone, white.... 75

11. Limestone, light bluish gray, non-magnesian, argillaceous, in thin flaky chips.. 50

to. Shale, green, pyritiferous

9. Sandstone, grains rather coarse, rounded, white and pinkish................ 9o

8. Shale, indurated, slightly arenaceous, fine grained, gray, green and purplish...... 30

7. Dolomite, light gray, arenaceous........ 60

6. Dolomite, light buff, arenaceous........ so 1300 
THICKNESS, DEPTH.

5. Dolomite, buff, arenaceous............ $100 \quad 1400$

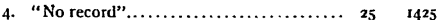

3. "Sandstone" $\ldots \ldots \ldots \ldots \ldots \ldots \ldots \ldots \ldots$, $14 \ldots \ldots \ldots$

2. "Limestone" $\ldots \ldots \ldots \ldots \ldots \ldots \ldots \ldots \ldots$ 100 $\mathbf{1 5 3 5}$

I. Dolomite, in minute fragments, with large admixture of silicious sand........... $\quad 1797$

SUMISTARY.

THICKNESS.

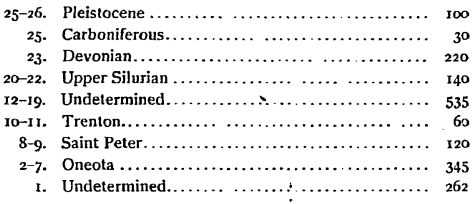

VIII. Davenport, Kimball House IVell. (Elevation, fig9 feet above tlde.)

THICKNESS, DEPTH.

15. "Modified Drift"

14. Limestone, magnesian, compact, of fine texture, hard, light and dark gray in color $67 \quad 80$

13. Limestone, softer, lighter colored, similar in composition and texture........... $48 \quad 128$

12. Dolomite, hard, pure, subcrystalline, vesicular, light greenish gray, with casts and moulds of fossils................ $47 \quad 375$

I I. Dolomite, as above, darker in color..... I30 305

10. Dolomite, as No. 12................ I $20 \quad 425$

9. Dolomite, light, bluish gray, with white chert.......................... $23 \quad 448$

8. Shale, black, pyritiferous, non-carbonaceous ........................ 27

7. Shale, blue..................... 90 565

6. Limestone, blue, argillaceous, fossiliferous. $125 \quad 690$

5. Dolomite, hard, rough, subcrystalline, medium dark buff................. 40

4. Sand, fine, buff, largely dolomitic, with rounded grains of quartz, also many grains of pyrite in minute, agglomerated crystals (water bearing) 
THICKNESS, DEPTH.

3. "Limestone," soft, yellow, magnesian (no sample $) \ldots \ldots \ldots \ldots \ldots \ldots \ldots \ldots \ldots \ldots \ldots, 75 \quad 88_{50}$

2. "Limestone," hard, buff, non-magnesian ( no sample) .................. 50 . 900

I. "Limestone," argillaceous, ferruginous ( no sample $). \ldots \ldots \ldots \ldots \ldots \ldots \ldots \ldots$ go 990

NUMBERS.

SUMMIARY.

THICKNESS.

15. Pleistocene or recent. $\ldots \ldots \ldots \ldots \ldots \ldots \ldots \ldots, 1_{3}$

i3-14. Devonian........................ 115

9-12. Upper Silurian......................... 320

6-9. Maquoketa .......................... 242

1-5. Undetermined.

\section{RECORDS OF DEEP WELLS IN THE MCGREGOR- CENTERVILLE SECTION.}

\section{McGregor Section (above the town).} (Elevation about 862 feet above tide.)

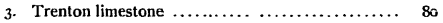

2. Saint Peter sandstone $\ldots \ldots \ldots \ldots \ldots \ldots \ldots \ldots \ldots$. 70

. Oneota limestone and shale............... 90

\section{Monticello Well.}

(Elevation 820 feet above tide.)

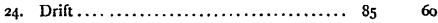

23. Dolomite, light buff................ I5 $_{5} \mathrm{8}_{5}$

22. Dolomite, lighter in color than above, porous, subcrystalline, with some chert, $40 \quad 100$

2I. Dolomite, hard, buff, porous, with considerable chert.................... 60 140

20. Dolomite, gray, with chert $\ldots \ldots \ldots \ldots \ldots .35 \quad 200$

19. Dolomite, hard, buff, porous .......... $30 \quad 235$

r. Shale, greenish, slightly calcareous ....... 265

17. Shale, greenish, slightly calcareous ...... $155 \quad 380$

16. Shale, dark brown, strongly bituminous, pyritiferous, slightly calcareous......... $30 \quad 420$

15. Shale, light greenish gray, magnesian.... 100 450

14. Shale, as above, with some gray subcrystalline dolomite, or magnesian limestone, $65 \quad 550$ 
THICKNESS. DEPTH.

13. Dolomite, as that above, and limestone, soft, white..................... $3^{0} \quad 6 \mathbf{r}_{5}$

12. Limestone, non-magnesian, in flaky chips, fossiliferous, rather soft, bluish gray in color.

II. Sandstone, grains rounded, fine ........ $25 \quad 775$

10. Dolomite, cream colored, with some quartz sand, probably from above............ $\quad 800$

9. Dolomite, as above, darker in color....... 820

8. Dolomite, light gray.................

7. Dolomite, light yellowish............. 975

6. Dolomite, highly silicious, or calciferous sandstone .................. 10 1025

5. Dolomite, hard, silicious, reddish buff .... 5 I035

4. Shale, yellowish green, non-calcareous .... Io40

3. Dolomite, gray..................... $100 \quad 108_{5}$

2. Sandstone, coarser than above, grains usually rounded, but some with crystalline faces .........................

I. Sandstone, light yellow, particles mostly angular $\ldots \ldots \ldots \ldots \ldots \ldots \ldots \ldots \ldots \ldots$

SUMMIARY.

19-23. Upper Silurian... ................. 180

15-18. Maquoketa $\ldots \ldots \ldots \ldots, \ldots \ldots \ldots \ldots \ldots \ldots \ldots \ldots, \quad 28$

12-14. Galena-Trenton...................... 225

I I. Saint Peter ...................... 25

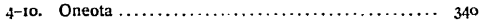

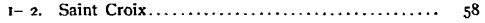

\section{Cedar Rapids Well. (See Section V.)}

XII. Sigourney Well. (Elevation $; 68$ feet above tide.)

THICKNESS. DEPTH.
24. Drift
93
98
23. Limestone, impure, earthy.......... 22
120
22. Limestone, cherty,.............. 15
135
21. Shale, calcareous ............... $20 \quad 155$
20. L.imestone and shale $\ldots \ldots \ldots \ldots \ldots \ldots \ldots$ ro 165
19. Limestone, hard, bluish gray......... $5 \quad 170$
18. Limestone, light, cherty............ $17 \quad 187$ 


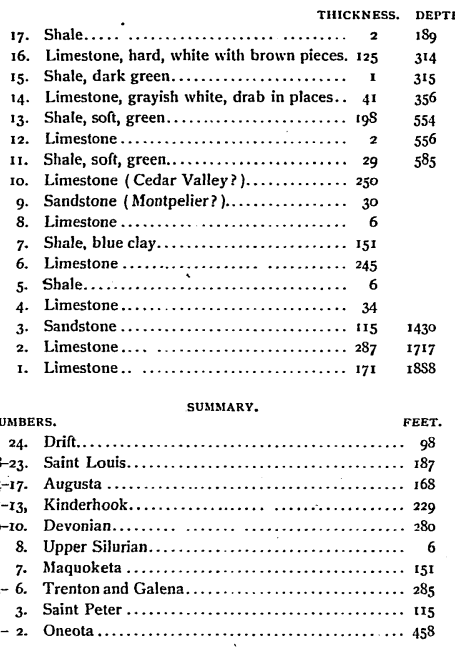

XIII. Ottumwa Well.

(Elevation 749 feet above tide.)

THICKNESS. DEPTH.

18. Drift....................... 23

17. Limestone, Saint Louis............. $23 \quad 46$

16. Shale, Saint Louis ................ 14 6o

r5. Sandstone, Saint Louis. ............ 30 90

14. Limestone, Saint Louis............... I4 104

13. Shale and limestone, Keokuk.......... 116 220

12. Sandstone, Burlington.............. 30 250

11. Limestone, Burlington.............. 180 430

10. Limestone, Kinderhook............ $15 \quad 445$ 


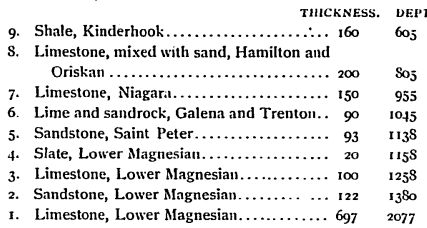

The above section is republished from an article by Gordon. The assignment of the geological formations is given by him. If the identification of 5 as Saint Peter be correct, 3 represents the upper Oneota, here 100, feet thick, with the heavy sandstone, 2, below. No. 1, comprehended under the single term limestone, 697 feet, which is probably as complex in fact as in the corresponding part of the Centerville section.

\section{Centerville Well.}

( Eleration ror7 above sea level.)

THCKNESS, DEPTH.

\begin{tabular}{|c|c|c|c|}
\hline 90. & Drift $\ldots \ldots \ldots \ldots \ldots \ldots \ldots \ldots \ldots \ldots$ & 50 & 50 \\
\hline S9. & Coal and shak $\ldots \ldots \ldots \ldots \ldots \ldots \ldots \ldots$ & & I57 \\
\hline SS. & Sandstone and calcareous shali.......... & & 500 \\
\hline 87. & Shale $\ldots \ldots \ldots \ldots \ldots \ldots \ldots \ldots \ldots \ldots \ldots \ldots$ & & 595 \\
\hline S6. & Sandstone, calciferous................. & 10 & 6ro \\
\hline 5. & $\begin{array}{l}\text { Limestone, hard, rough, gray, silicious, } \\
\text { (same also at } 620) \ldots \ldots \ldots \ldots \ldots \ldots \ldots\end{array}$ & 20 & 630 \\
\hline 84 . & Shale, calcareous . .................. & & 640 \\
\hline$S_{3}$. & Shale, light buff.................... & 70 & 650 \\
\hline 82. & Shale, samples from 670 to 700 feet........ & & 700 \\
\hline 3r. & $\begin{array}{l}\text { Shale, gritty, with small angular particles of } \\
\text { flint, a bluish gray non-magnesian line- }\end{array}$ & & \\
\hline & stone and white quartz sand.... . . . . . & Io & 715 \\
\hline So. & Shale (same as 725 ) $\ldots \ldots \ldots \ldots \ldots \ldots$ & 35 & 750 \\
\hline 79. & Shale, calcareous, or limestone argillaceous & 8 & 760 \\
\hline 78. & Shale $\ldots \ldots \ldots \ldots \ldots \ldots \ldots \ldots \ldots \ldots \ldots$ & 77 & 768 \\
\hline & $\begin{array}{l}\text { Limestone, white, non-magnesian, with } \\
\text { much white flint as chips, and shale..... }\end{array}$ & I0 & \\
\hline
\end{tabular}


THICKNESS. DEPTH.

76. Shale, calcareous ................. 855

75. Shale.................. $20 \ldots \ldots \ldots \ldots$

74. Shale, calcareous ............... no so $\$ 75$

73. Limestone, soft, white, non-magnesiau, with some white flint.............. 10 $\quad 885$

72. Limestone, silicious .............. 10 895

71. Shale.................... 10 905

7o. Limestone, dark brown, briskly effervescent with cold dilute hydrochloric acid, and much gray chert, as chips in shale., $20 \quad 915$

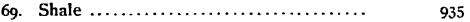

68. Shale, calcareous $\ldots \ldots \ldots \ldots \ldots \ldots \ldots \ldots$.

67. Shale .......................... 965

66. Shale, arenaceous................. 975

65. Shale....................... 115 1023

64. Limestone, bluish gray, non-magnesian, pyritiferous, siliceous ............. 1030

63. Shale... ..................... 60 1090

62. Limestone, fine-grained, white, non-magnesian................ 10 $1100 \ldots \ldots$,

6r. Shale ...................

6o. Shale, calcareous at $1140 \ldots \ldots \ldots \ldots \ldots$ 20 1150

59. Limestone, gray, rather soft, non-magnesian...................... $8 \quad 1160$

58. Shale, arenaceous, samples from $1168 \ldots \ldots 32 \quad$ II 99

57. Limestone, gray, non-magnesian, silicious (water bearing )................. 10 o 1200

56. Shale, arenaceous at $1210 . \ldots \ldots \ldots \ldots \ldots$ 20 1220

55. Limestone, argillaceous, or shale, calcareous $\ldots \ldots \ldots \ldots \ldots \ldots \ldots \ldots \ldots$ so

54. Limestone, light gray, argillaceous, briskly effervescing in cold dilute $\mathrm{HCl} . . . . . \ldots$. 20

53. Limestone, compact, fine-grained, light bluish gray $\ldots \ldots \ldots \ldots \ldots \ldots \ldots \ldots \ldots$ 10 1260

52. Shale, calcareous, or limestone argillaceous, light yellowish in color......... 10 1270

5I. Limestone, hard, somewhat argillaceous, brown and bluish gray

1280

5o. Limestone, white, compact, moderately hard, non-magnesian, with some darker gray in color and much shale in flakes. . 20

49. Shale, calcareous, or limestone argillaceous, light green in color at $1300 \ldots \ldots \ldots$ io 13 to

48. Shale, blue, free from grit, calcareous.... 30 1340 
THICKNESS. DEPTH.

47. Limestone, argillaceous, or shale calcareous, slightly arenaceous, buff in color... 10 1350

46. Limestone, magnesian, argillaceous at $1360 \quad 20 \quad 1370$

45. Shale, blue at $1380 \ldots \ldots \ldots \ldots \ldots \ldots \ldots$ 20 1390

44. Limestone, soft, bluish, non-magnesian, with some white chert and $\mathrm{much}$ shale............................

43. Limestone, hard, light bluish gray, compact, fine-grained, non-magnesian, cherty.....

42. Shale, blue, calcareous, briskly effervescing in cold dilute $\mathrm{HCl}$, not gritty but leaving after treatment with acid a slight residue of flint flakes and angular quartz (microscopic).....................

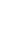
fine powder containing also grains of light colored limestone................

40. : Sandstone, light gray, calciferous.........

39. Sandstone, buff, calciferous ............

38. Sandstone, fine, white...............

37. Sandstone, calciferous, with some fragments of blue shale.............. 5

36. Limestone, highly silicious, magnesian....

35. Limestone as above................

34. Limestone as above, samples from $1510 .$.

33. Limestone, hard, compact, gray, subcrystalline, slightly magnesian, with gray sandstone and much buff shale.............

32. Limestone, light buff, magnesian, residue after solution of quartz and chert........

3r. Limestone, light buff, magnesian, residue cherty ..........................

3o. Limestone, light buff, magnesian, residue after solution composed of flakes of chert and some rounded grains of quartz from

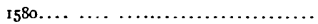

29. Dolomite, magnesian, limestone, dark buff, cherty, and slightly arenaceous, samples from 1610

1490

28. Limestone, hard, rough, dark gray, highly siliceous.

1640

27. Limestone, magnesian or dolomite, buff, residue arenaceous and cherty, samples from $1650 . \ldots \ldots \ldots \ldots \ldots \ldots \ldots . . . \ldots \ldots$ 
THICKNESS. DEPTH.

26. Limestone, magnesian or dolomite, light yellowish gray, large cherty residue.... $\quad$ I680

25. Limestone, magnesian............... $\quad 1690$

24. Limestone, magnesian, dark gray, pyritferous, with much green shale and moderately soft light bluish gray limestone, magnesian.

1710

23. Limestone, magnesian, hard, buff, residue of chert and rounded grains of quartz

22. Shale, blue, soft.

21. Sandstone, in clear quartzose grains, moderately fine and rounded, with a little green shale from $1740 . . \ldots \ldots . . . . .$.

20. Sandstone, as above, white in color from $1760 \ldots \ldots \ldots \ldots \ldots \ldots \ldots \ldots \ldots \ldots \ldots, 40$

19. Dolomite, in buff powder, containing sand which may be derived from above, from

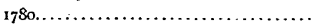

18. Dolomite, gray, from $1805 \ldots \ldots \ldots \ldots \ldots$

17. Dolomite, light drab ............. n to

16. Sandstone, very fine, white, with dolomite and a little chert from 1 sgo.

15. Sandstone, grains rounded and angular, with considerable dolomite and chert, samples from rgr $5 \ldots \ldots \ldots \ldots \ldots \ldots$.

14. Sandstone, light yellowish-gray, with much dolomite and chert, also much finely laminated green shale, sample from 1945

13. Sandstone, as above, except that green shale is absent, sample from $1965 \ldots \ldots$ r... 105

12. Sandstone, fine particles, angular, light yellowish-gray, with a slight admixture of white dolomite, a little green shale.... I 30

11. Sandstone, calciferous or dolomite, arenaceous, buff, particles of quartz in drillings, angular

10. Dolomite, gray, highly cherty, with flakes of green shale

9. Dolomite, light gray, highly cherty......

8. Dolomite, with considerable fine angular quartz sand

7. Dolomite, cherty, light yellowish gray, samples from $2250 . . \ldots \ldots \ldots \ldots \ldots \ldots \ldots$. 
THICKNESS. DEPTH.

6. Sandstone, calcareous or dolomite, arenaceous, grains rounded, smooth and of moderate size, with chips of very hard, gray, bluish dolomite ............... $68 \quad 2352$

5. Dolonite, gray, cherty samples from $2420, \quad 2427$

4. Dolomite, light gray, subcrystalline, with much green slaty shale .............. $\quad 2435$

3. Dolomite, as above, with less shale....... 2440

2. Dolomite, siliceous, light buff............ 2445

I. Dolomite, gray, quartziferous and cherty,

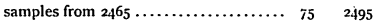

The interpretation of this section is made difficult by the absence of fossils to mark any horizon and because of probable lithological changes in the southward extension of the geological formations. Fortunately the drillings below 500 feet are exceptionally satisfactory in every respect. They are ample in quantity and were taken at such short intervals that no formation of any thickness could have been overlooked. The heavy shales above 1240 feet with their thin beds of interbedded limestones probably represent the entire Mississippian section and a portion also of the Coal Measures.

The shales and argillaceous limestones from 1240 to 1430 feet may be Devonian. Beneath these the Upper Silurian appears as a sandstone, and between 1480 feet and 1540 feet it merges into the arenaceous Trenton, the Maquoketa shales being apparently absent here as at Ottumwa. The basal shale of the Trenton (No. 22) immediately overlies the well-marked sandstone of the Saint Peter, Nos. 20 and 21, here 40 feet thick. The. upper part of the Oneota, subjacent, is also well defined in Nos. 17-19 and is 110 feet thick. The passage beds of this dolomite to a typical sandstone are seen in Nos. 13 to 16, arenaceous dolomites, calciferous sandstones 14 G. Rep. 
or interbedded sandstones and dolomites 105 feet thick. The typical sandrock itself appears as a purer sandstone in No. 12, thickness 130 feet. The lower Oneota, Nos. 1 to 11, consists of cherty dolomitic beds interstratified in places with arenaceous layers which at No. 6 seem to attain considerable thickness. The thickness of this formation so far as penetrated by the drill is 370 feet. 